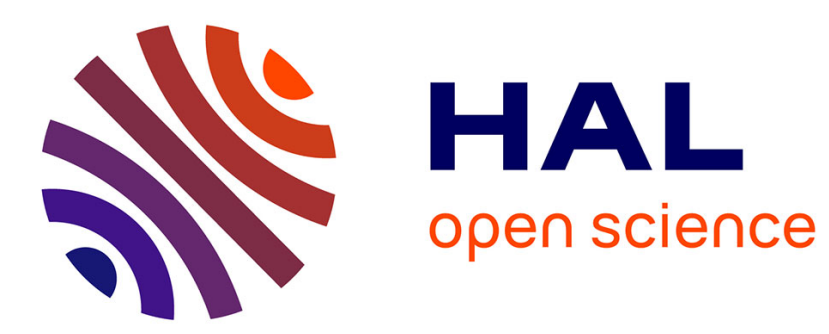

\title{
Rethinking family relations through the allocation of emigration's resources: Senegalese migrants' use of e-commerce
}

\author{
Melissa Blanchard
}

\section{- To cite this version:}

Melissa Blanchard. Rethinking family relations through the allocation of emigration's resources: Senegalese migrants' use of e-commerce. Migration Letters, 2013, 10 (1), pp.47-56. 10.33182/ml.v10i1.110 . hal-02990206

\section{HAL Id: hal-02990206 https://hal.science/hal-02990206}

Submitted on 5 Nov 2020

HAL is a multi-disciplinary open access archive for the deposit and dissemination of scientific research documents, whether they are published or not. The documents may come from teaching and research institutions in France or abroad, or from public or private research centers.
L'archive ouverte pluridisciplinaire HAL, est destinée au dépôt et à la diffusion de documents scientifiques de niveau recherche, publiés ou non, émanant des établissements d'enseignement et de recherche français ou étrangers, des laboratoires publics ou privés. 


\title{
Rethinking family relations through the allocation of emigration's resources: Senegalese migrants' use of e-commerce BLANCHARD $^{*}$
}

\begin{abstract}
This paper focuses on a website which allows Senegalese migrants to purchase at a distance provisions they want delivered in Senegal, in order to overcome the problem of control over remittances' use. It shows how new economic practices may carry new social meanings, in this case a shift in the conception of obligations and roles within the family. Whether it is their exposure to diverse ways of living that leads migrants to rethink their family relations, or whether migration just accelerates the consolidation of ideas that already exist in the home country, has yet to be determined.
\end{abstract}

Keywords: Senegal, migration, remittances, family, on-line shopping.

\section{Introduction}

A vast scholarship has underlined the importance of remittances in shaping new social and economic landscapes in the countries of out-going migration. In particular, the connection between remittances and development has been extensively analysed, with authors debating on whether or not remittances foster development in the receiving countries (Durand, et al. 1996, Taylor 1999, Nyberg Sørensen 2005, De Haas 2010). Some works underscore that remittances have an important role also on the social level, since money transfers are tokens of the migrant's will to be part of networks of kinship and exchange (Carling 2008, Åkesson 2011). Much less has been said, though, about the social content of what migrants remit to their families and to their communities of origin.

Social remittances, as Levitt says, are "the ideas, behaviours, identities and social capital that flow from receiving- to sending-country communities" (Levitt 1998: 927). They are transmitted when migrants return, temporarily or permanently, to their home country and when non-migrants visit their family abroad, but also through means of communication such as phone calls, letters, the Internet. Social remittances stimulate change in different spheres, from local status hierarchies to gender relations, from consumer habits to family relations and political life (Vertovec 2004, Levitt and Lamba-Nieves 2011). Through this lens migration appears not only as a result of social transformation going on in outward migration countries, but as a factor of social change in itself, which spreads over the societies it involves (Castles and Miller 2009).

\footnotetext{
${ }^{*}$ Melissa Blanchard is a Post-doc Fellow, University of Trento, Italy.

E-mail: blanchard.melissa@gmail.com.
} 
Social remittances derive from migrants' interaction with the host society and correspond to different forms of combining previous practices, ideas and knowledge (Levitt 1998: 931). They are thus a local-level form of cultural diffusion, generated by migration. From an anthropological point of view two major remarks can be made about the use of this concept, encouraging authors to further refine it.

The first concerns the use of the notion of culture, which is not explicitly defined, but in certain texts seems to be considered as a stable set of elements typical of a specific geographic setting or population (Levitt, 1998: 930). Culture is the object of a passionate debate in anthropology, which is too complex to discuss here. Suffice it to remember that it urges us to consider cultures as evolving nebula more than as once-and-for-all established sets of constituents, as living ensembles of different elements that can be used and performed contextually (Barth 1969, Augé 1994), undergoing transformation in a continuous process of "metissage" (Amselle 1990).

The second concerns the tendency to focalize mostly on transfers of Western ideas and practices to countries of out-going migration. My intention here is not to point to the need to discuss whether host societies offer migrants positive or negative role models to embrace (Levitt 1998), or to acknowledge that social remittances travel both ways or circulate (Levitt and Lamba-Nieves 2011), but to stress the risk implicitly contained in considering that social and economic development would be brought about by the absorption of "positive" Western ideas and practices. This ethnocentric view, aiming at imposing the Western idea of development, vaguely echoes a colonialist ideology. It is nowadays adopted by neoliberal globalization theories arguing that Western models of privatization and entrepreneurship are fundamental for development and should be introduced in Southern countries yet the evidence suggests that they have led to greater inequality (Castles and Miller 2009).

After outlining some of its limits, I shall employ the notion of social remittances as a heuristic tool to study flows of social transformation. In this paper I shall contribute to the debate on social remittances by analysing a case of collective reorganization of economic remittances that suggests how new economic practices may also carry new social meanings. This reorganization was initiated by Senegalese migrants wishing to overcome the problem of control over the use of remittances they send, and was achieved by establishing a website offering them the opportunity to purchase at a distance provisions they want delivered in Senegal. The analysis is based on material I gathered in Dakar in 2009 during an anthropological inquiry into Senegalese returnees' entrepreneurial activities. In the field I carried out semi-structured, openended interviews and participant observation with the website's staff and users. Most of the time was spent following the local team's daily activities in the office, in the warehouse and on delivery runs to migrants' households in 
Dakar. As we will see, the case I shall present is a "niche" experience, touching a relatively small number of migrants and family members $;{ }^{1}$ nonetheless it deserves analysis, as it shows social transformations that are taking place under the impulse of migration.

\section{Senegalese migration and the central role of the migrant-left behind nexus}

Migration has been a fact of life in Senegal since the end of the Second World War. Initially flows were directed to France, the former colonial power, whereas today Italy, Spain and the United States are the most sought-after destinations (Diop 2008). In Senegal, as in other geographical contexts, emigration is rarely an individual adventure. Rather, it is the result of a household project that often involves the entire extended family as a source of material, logistic and emotional support for the individual who leaves (Riccio 2002). In return, migrants are assumed to share their revenues with the original family, through monthly remittances and other occasional funding for special expenses, such as healthcare, schooling or family celebrations. If a migrant wants to keep his place in his group of origin, his moral duty is to fulfil this expectation. As an elderly headman explains "children are like a credit to us. If they go to France, it is to repay what they owe... Those who go are not doing the right thing if they do not think of their father, their family, the village" (Quiminal 1998: 286).

Yet in explaining why they emigrated, in addition to the main reasonwhich has to do with severe economic difficulties and the need to find a source of family income abroad — some Senegalese migrants also refer to their desire to follow a personal path based on individual projects, getting away from families that they often perceive as "financial predators" (Dieng 2008). Judging from my fieldwork, even migrants who take a distance from families, however, rarely severe their ties with them (Blanchard 2007). They remain bound to the obligation to support the families that stayed behind, so as to reaffirm their social affiliation but also to show their success in migration. The principle of reciprocity governs the remittance process: in West-African families, what has been given must be returned (Meillassoux 1975). When children become adults, in other words, they are strongly expected to indefinitely repay the feeding, care and education they received, following the bonding logic of an "infinite debt" (Marie 1997). This obligation is enforcing for migrants, but also for the family members who stay behind. Moreover, sending remittances can also be a form of social insurance (Timera 1996, Bryceson and Vuorela 2002), as it enables migrants to maintain a network of clients who are also potential debtors to whom they can turn to seek support in case of difficulty.

As in other contexts, Senegalese migrants' families use remittances mostly as income: they spend them on food, clothing, housing, education and health

${ }^{1}$ The number of users of the site ranged between 50 and 150 at the time of my research. 
services, while little money is left for "productive" investments that could bring them economic independence (Goldring 2004). In a highly unfavourable context like that of contemporary Senegal, emigration money is a structural necessity for many families, who depend on it for their survival (Gubert 2008). But remittances are often used also for purposes that go beyond what migrants may have wanted.

\section{Migrants' strategies to assume control over the use of remittances: the spread of e-commerce}

The problem of migrants' lack of control over the way remittances are used is well documented in the literature (Ashraf, et al. 2011), as is that of productive inefficiencies in intra-households allocation (Duflo 2003). The migrants I interviewed, both in Dakar and in previous research in Southern France, felt that the demands of families were often pressing, forcing them to send a significant portion of their resources without being able to invest them in the personal projects they would like to carry out (Blanchard 2011). They perceived also that families demanded much more than would have been necessary to meet day-to-day needs and complained about the conspicuous spending dynamics that develop around remittances. The migration project has a fundamental role in determining migrants' plans regarding the allocation of their resources. When migration is considered as definitive or as a long-term project, and especially when family reunification abroad is achieved, migrants tend to reorient their expenses toward the immigration country (Poiret 1996, Streiff-Fenart 2004). As a consequence, the original families' repeated demands for help are felt as even more constraining.

Senegalese migrants have put different strategies in place to cope with the problem of controlling the use of remittances. These range from individual actions aiming at reducing the amount of remittances or the spread of beneficiaries - at the price of creating conflicts that are resolved piecemeal- to entrepreneurial projects involving family members who stayed behind, even if, from what I could observe in the field, the funds that had been sent in order to meet business needs rapidly disappeared in family circuits. The literature reports also the spread of joint responses by which groups of migrants invest part of their income in the development of the community of origin through collective remittances, so as to unravel the dependency relationship that binds it to migration (Daum 1996, Quiminal 1998, Dia 2008).

A highly original example of collective response that aims, through the modification of individual practices, at containing the dependence dynamics that arise around monthly remittances is the case of Senboutique.com, a website that offers mail-order purchase of groceries, appliances and building materials to be delivered in Senegal.

This site, the first of its kind serving Senegal, was born in 2006 in response to a demand expressed by Senegalese women entrepreneurs (mostly hairdressers) who had been living in the United States for more than a decade and 
who wished to contrast original families' unlimited demands and to cut out an area of personal financial autonomy. The fact that women are behind this idea is certainly not trivial. Women are more numerous and highly dynamic in contemporary international mobility (Castles and Miller 2009).As the literature underlines, they often send more remittances than men, even if on average they earn less (Tacoli 1999, Salazar Parreñas 2001). This is because of their gendered role in the family and because of specific cultural values (Boyd 1989). Senegalese women integrate, through socialization, strong injunctions to conform to a specific gendered role - that of obedient daughters, sisters and wives exclusively devoted to family life (Diop 1985). Even if they rework this role or adhere to it only partially, supporting the original family through migration, especially when it comes to elderly women, remains essential to the definition of their social identity. Moreover, women are more skilled than men at calculating the relation between the money they send and the domestic spending it is supposed to cover - a sum which Senboutique.com's founders saw constantly exceeded. These migrant women appealed then to a Senegalese computer engineer who had settled in Washington to develop a website for the long-distance sale of provisions.

Here is how one of the founding partners, who returned to Senegal after 10 years in France, traces the genesis of Senboutique.com:

The Senegalese who are abroad send money to help the families they have left. But you know how Senegalese homes are, you send 100,000 francs (CF A), they immediately go and buy things they need for 40,000 francs, and the remaining 60,000 goes into tontines, ${ }^{2}$ parties, and things like that. By the 15th the money is finished, there is nothing left and then they call you again.

Senboutique.com offers everything necessary to provision a family. The purchase of provisions is organized in baskets, or in units. The baskets have been carefully designed to meet families' needs and to correspond as closely as possible to the grocery-shopping practices of local people, offering firstchoice products available on the local market.

The basic product is the Sakanal Basket, ${ }^{3}$ designed for small, medium and large families. ${ }^{4}$ The products offered are the same in each format, but the amount varies depending on family size, being quantified to meet a family's needs for a month. The buyer has the option of adding products he selects personally, or of including a gift of cash. The small-family Sakanal Basket is priced at USD $130^{5}$ and includes a bag of rice, a case of peanut oil, a case of sugar, a large jar of tomato concentrate, four packets of powdered milk and a

\footnotetext{
2 Tontines are a sort of informal lottery, in which mainly women participate.

3 Sakanal means "saving," "not wasting" in Wolof.

${ }^{4}$ A small family is intended as being composed of 5-6 persons.

5 According to the website www.senboutique.com (accessed on 29/03/2012). Payment for purchases is also accepted in euros, Canadian dollars, Swiss francs or British pounds, in order to reach as large a public as possible.
} 
case of laundry soap. Other baskets are designed for special occasions. Examples include the "Ramadan Special Basket"-which adds to the "basics" luxury items such as beef sausage, butter, Gruyere cheese, extra sugar and coffee, chocolate and dates_or the "Tabaski Special Basket"6 that includes the opportunity to buy a mutton.

In 2009 Senboutique.com served from fifty to one hundred and fifty clients per month and the number of clients increased in concomitance with special recurrences and festivities. Deliveries were made by employees, who travelled by taxi to destinations in Dakar and in Senegal's biggest cities until 2010, when a van was bought to lower delivery costs.

\section{Reshaping remittances: social challenges of a new support practice}

During my fieldwork, I observed that while some migrants' families adapted to this new form of remittances, others tried to oppose to it. As one Senboutique.com delivery man reports:

Senboutique.com causes a big problem here in Dakar. For example, old Mrs. Diagne, ber son sends her money, after two months be's been sending her food she starts to attack me, complaining that the rice is no good, that the soap is no good. And then of course she begins to bother her son. And it's the same thing she would buy in the store! Her son stops for two months; the third month he sends us another order. When we take it around we find the lady's daughter, and she asks: "why has it been two months that you haven't brought any provisions? These two months we've had so many problems, we'd gone through everything by the 15th." When I had Mrs. Diagne's son on the phone from the U.S., he understood his mother's strategy and said, "don't pay any attention to what my mom says, just deliver the stuff and that's it."

This story concisely summarizes a number of contentious situations delivery men have faced. Some families, unwilling to complain directly to their migrants (who they fear might stop supporting them), address their grievances to delivery personnel. I think it unlikely that the complaints really concern the quality of the commodities they receive, as these are among the highest quality, most frequently purchased goods one can find on the local market. The complaints seem instead to express the disappointment of not being able to manage the money from emigration, that some families feel is their due and that they can spend in different sectors of the household economy, of which covering subsistence requirements is just one.

This is a misunderstanding that generates tensions between the family members who have left and those who have stayed behind. Substituting monthly orders for monthly remittances, migrants seem to send a message indicating a change in the dynamics of assistance and a reorganization of roles and relationships within the family. They redefine the amplitude and the use

${ }^{6}$ The Senegalese name for the Feast of Sacrifice. 
of emigration resources, turning the emphasis away from the repayment of an "infinite debt" owed to the family of origin (Marie 1998), toward a moral duty of support measured in relation to the real needs of the household. Ultimately, what migrants seem to say and remit is that the individual who migrates cannot be considered an inexhaustible source of income, blindly bound by moral obligations.

\section{Conclusions}

Although it must be acknowledged that the findings of my research are determined by the nature of the inquiry I have conducted, based on a casespecific ethnographic study, two broad conclusions can be drawn.

First, Senegalese migrants continue to maintain close ties with their original families, both emotionally and through remittances. The moderate but constant growth of Senboutique.com user numbers I observed, however, points to a transformation in rooted support practices that corresponds to a changed conception of obligations and roles within the family. In this new form of remittance it is not only money, or goods, that are sent, but also new ideas of family relations. Whether it is their exposure to diverse ways of living, and of making a living, that leads migrants to rethink and rework their relationships with their original families, or whether migration just accelerates the consolidation of ideas and aspirations concerning autonomy that already exist in the home country, has yet to be determined.

Second, the transformation of remittance practices and the logic of support that underlies them causes conflicts between migrants and the families they leave behind. My investigations, like much recent research, show that, rather than a compact entity acting rationally and consistently (Stark and Bloom 1985), the extended family household is an arena where various members interact, different perceptions and aspirations compete, and new practices emerge (Asis, et al. 2004, Toyota, et al. 2007).

Scholarship shows that the effectiveness of social remittances depends not only on the content of such remittances, but also on the social status of the senders and receivers and on their position in the life-cycle-in other words, on the strength of their respective bargaining positions in the household arena. In the case I have presented, left-behind families, being in a difficult material situation and often lacking any other form of revenue, come to depend on remittances and are obliged to accept the new practice that is imposed on them. One wonders, though, if such imposition can be considered a legitimate and successful way of transmitting social remittances, or if voluntary adhesion is fundamental for social remittances to be accepted and integrated in new ways of living. The use of e-commerce in place of economic transfers is too recent a phenomenon to allow one to judge the reception of the ideas it carries. Like the balance of power between senders and receivers, it is a matter for further research. 


\section{References}

Åkesson, L. (2011). "Remittances and Relationships: Exchange in Cape Verdean Transnational Families". Ethnos, 76 (326-347):

Amselle, J.-L. (1990). Logiques métisses. Anthropologie de l'identité en Afrique et ailleurs. Paris: Payot.

Ashraf, N., Aycinena, D., Martínez, C. A. and Yang, D. (2011). Remittances and the Problem of Control: A Field Experiment Among Migrants from El Salvador. Mimeo. The University of Michigan.

Asis, M. M. B., Huang, S. and Yeoh, B. S. A. (2004). "When the light of the home is abroad: Unskilled female migration and the Filipino family". Singapore Journal of Tropical Geography, 25 (2): 198-215.

Augé, M. (1994). Le sens des autres. Paris: Fayard.

Barth, F. (eds) (1969). Ethnic groups and boundaries: the social organizaiton of culture difference. Boston: Little, Brown \& Co.

Blanchard, M. (2007). "Migrantes sénégalaises "en solitaire" à Marseille. Des statuts ambigus entre marginalité et quête de reconnaissance". Diasporas. Histoire et sociétés, 11 111-122.

Blanchard, M. (2011). "Entre logiques de redistribution et volonté d'entreprendre: les relations complexes des migrantes sénégalaises avec leurs familles d'origine". Revue Européenne des Migrations Internationales, 27 (2): 139-159.

Boyd, M. (1989). "Family and Personal Networks in International Migration: Recent Developments and New Agendas". International Migration Review, 23 (3): 638670.

54 Bryceson, D. F. and Vuorela, U. (eds) (2002). The transnational family: New European fontiers and global networks. New York: Berg.

Carling, J. (2008). "The human dynamics of migrants transnationalism". Ethnic and Racial Studies, 31 (8): 1452-1477.

Castles, S. and Miller, M. J. (2009). The Age of Migration: International Population Movements in the Modern World. Basingstoke and New York: Palgrave Macmillan.

Daum, C. (1996). La contribution des immigrés au développement de leur pays: six études de cas. Paris: L'Harmattan.

De Haas, H. (2010). "Migration and Development: A Theoretical Perspective". International Migration Review, 44 (1): 227-264.

Dia, H. (2008). "Villages multi-situés du Fouta-Toro en France : le défi de la transition entre générations de caissiers, lettrés et citadins". REVUE Asylon(s), 3 (Migrations et Sénégal): http://www.reseau-terra.eu/article713.html.

Dieng, S. A. (2008). "Déterminants, caractéristiques et enjeux de la migration sénégalaise". REVUE Asylon(s), 3 (Migrations et Sénégal): http://www.reseauterra.eu/article 709. html.

Diop, A. B. (1985). La famille wolof. Paris: Karthala.

Diop, M. C. (eds) (2008). Le Sénégal des migrations: Mobilités, identités et sociétés. Paris: Karthala.

Duflo, E. (2003). "Grandmothers and Granddaughters: Old-Age Pensions and Intrahousehold Allocation in South Africa". The World Bank Economic Review, 17 (1): 1-25.

Durand, J., Parrado, E. A. and Massey, D. S. (1996). "Migradollars and Development: A Reconsideration of the Mexican case". International Migration Review, 30 (2): 423-444. 
Goldring, L. (2004). "Family and Collective Remittances to Mexico: A Multidimensional Typology". Development and change, 35 (4): 799-840.

Gubert, F. (2008). "(In)cohérence des politiques migratoires et de codéveloppement françaises. Illustrations maliennes". Politique africaine, 109 (March): 42-55.

Levitt, P. (1998). "Social remittances: migration-driven local-level forms of cultural diffusion". International Migration Review, 32 (4): 926-948.

Levitt, P. and Lamba-Nieves, D. (2011). "Social Remittances Revisited". Journal of Ethnic and Migration Studies, 37 (1): 1-22.

Marie, A. (eds) (1997). L'Afrique des individus. Itinéraires citadins dans l'Afrique contemporaine. Paris: Karthala.

Marie, A. (1998). "L'échange : sous le don, la dette". Sciences Humaines, 23: 28-31.

Meillassoux, C. (1975). Femmes, greniers et capitaux. Paris: Maspero.

Nyberg Sørensen, N. (2005). Migrant remittances, development and gender. Copenhagen: Dansk Institut for Internaitonale Studier.

Poiret, C. (1996). Familles africaines en France: Ethnicisation, ségrégation et communalisation. Paris: L'Harmattan.

Quiminal, C. (1998). "Familles, projets et capitaux". In: B. Schlemmer (eds) Terrains et engagements de Claude Meillassoux. Paris: Karthala.

Riccio, B. (2002). "Senegal is Our Home: The Anchored Nature of Senegalese Transnational Networks". In: N. Al-Ali and K. Koser (eds) New Approaches to Migration? Transnational Communities and the Meaning of Home. London: Routledge.

Salazar Parreñas, R. (2001). Servants of Globalization: Women, Migration and Domestic Work. Stanford: Stanford University Press.

Stark, O. and Bloom, D. E. (1985). "The New Economics of Labor Migration". American Economic Review, 75 (2): 173-178.

Streiff-Fenart, J. (2004). "Familles et immigration". Historiens et Géographes, 385 139146.

Tacoli, C. (1999). "International migration and the restructuring of gender asymmetries: continuity and change amongst Filipino labor migrants in Rome". International Migration Review, 33 (3): 658-682.

Taylor, J. E. (1999). "The new economics of labour migration and the role of remittances in the migration process". International Migration, 37 (1): 63-88.

Timera, M. (1996). Les Soninkés en France. Paris: Karthala.

Toyota, M., Yeoh, B. S. A. and Nguyen, L. (2007). "Bringing the 'Left Behind ' Back into View in Asia: a Framework for Understanding the 'Migration-Left Behind Nexus'". Population, Space and Place, 13 (3): 157-161.

Vertovec, S. (2004). "Migrant Transnationalism and Modes of Transformation". International Migration Review, 38 (3): 970-1001. 
Reproduced with permission of the copyright owner. Further reproduction prohibited without permission. 